\title{
Döviz Cinsinden Alımlarda Döviz Alım Opsiyonları Ve Riskten Korunma Muhasebesi
}

\author{
Mehmet Ünsal MEMIȘ* \\ Kayahan TÜM**
}

\section{$\ddot{O Z Z E T}$}

Döviz cinsinden gerçekleştirilen işlemler neticesinde işletmeler, döviz kurlarında meydana gelen dalgalanmalar nedeniyle kur risklerine maruz kalmaktadırlar. Issletmeler, kur risklerini ortadan kaldırmak veya kur risklerinden asgari düzeyde etkilenmek üzere türev araçlara başvurmaktadırlar. Bu türev araçlardan biri de "döviz opsiyon sözleşmeleri" dir. Bu çalışmada, döviz opsiyon sözleşmeleri ile ilgili teorik bilgiler sunulmakta ve ardından da satın alma işlemlerinde döviz opsiyon sözleşmesi aracının kullanıldı̆̆ı bir örnek üzerinde Türkiye Muhasebe Standartları Kurulu tarafindan hazırlanıp daha sonra geri çekilmiş olan taslak hesap planı çerçevesinde- muhasebeleştirme uygulaması yer almaktadır. Örnek uygulamada, işletmenin döviz opsiyon sözleşmesi satın almak suretiyle, kur artışlarından daha az etkilendiği gözlenmektedir.

Anahtar Kelimeler: Döviz Opsiyon Sözleşmesi, Alım Opsiyonu, Satım Opsiyonu, Opsiyon Primi.

JEL Sinıflandirması: M40, M41.

\section{Foreign Currency Purchase Options And Risk Aversion Accounting in Foreign Currency Purchases}

\section{ABSTRACT}

As a result of foreign currency operations businesses are subject to exchange rate risks due to changes in exchange rates. Businesses appeal derivatives to eliminate the foreign currency risks and for exposuring minimal impact from the foreign currency risks. One of these derivatives is the foreign currency option contracts. In the first part of the study, theoretical information about foreign currency option contracts will be presented. Following to this part, an accounting case -based on the framework within the draft plan by Turkish Accounting Standards Board - that involves foreign currency option contracts in purchasing operations. In the example case it can be observed that the firm can be less affected by exchange rate increases by purchasing foreign currency option contract.

Keywords: Foreign Currency Option Contract, Put Option, Call Option, Option Premium.

Jel Classification: M40, M41.

\footnotetext{
* Doç.Dr. Mehmet Ünsal Memiş, Çukurova Üniversitesi, İktisadi İdari Bilimler Fakültesi, mmemis@cu.edu.tr

** Yrd.Doç.Dr. Kayahan Tüm, Mustafa Kemal Üniversitesi, İktisadi İdari Bilimler Fakültesi,

kayahantum@mku.edu.tr
} 


\section{GİRIŞ}

Farklı sektörlerde farklı piyasa şartlarında faaliyet gösteren işletmeler çok sayıda riskle karşılaşmaktadırlar. İşletmeler tarafından, karşılaşılan bu risklerin olumsuz ekonomik etkilerini asgari düzeye indirgemek üzere kullanılan yöntemlerden biri de türev ürün sözleşmeleridir. Türev ürün sözleşmeleri sayesinde yatırım ve işlem yapılan piyasalardaki işlem maliyetleri azalmakta, piyasaların derinliği artmakta ve böylelikle riskten korunma amacına katkı sağlanmaktadır (Karagözoğlu, 2005:16). Türev ürünler, genel olarak fiyatı ya da değeri başka bir finansal ya da finansal olmayan varlı̆̆ın değeri doğrultusunda belirlenen ve kullanıcılarına; fiyat, faiz ve kurlardaki gelecekte beklenmeyen değişimlere karşı korunma; tahmin ve beklentilere dayanarak gelecekteki fiyat artışlarından veya fiyat düşüşlerinden kar elde etme ve piyasalar arasındaki fiyat farklılıklarından risksiz kazanç sağlama imkanı veren finansal araçlar olarak ifade edilebilir (Anbar ve Alper, 2011:78). İşletmeler, döviz riskinden korunmak amaciyla forward, future, option, swap vb şeklinde türev ürünlere başvurma yoluna gidebilmektedirler.

Döviz riski, belli bir para biriminin yabancı para birimi karşısında değerinde değişim olma ihtimalidir. Bu risk, döviz fiyatlarında beklenmeyen değişimlerin yarattığı risk türüdür. Belli bir zaman sürecinde, spot kurlarda meydana gelen değişimin bilanço değerleri ya da kar veya zarar rakamları üzerinde etkisi olursa işletme için döviz riski ortaya çıkmaktadır (Kaygusuz, 1998:6).

İşletmelerin karşılaştıkları döviz riskleri işlem riski, çeviri riski ve ekonomik risk olmak üzere üç grup altında toplanmaktadır. Bu çalışmanın konusu gereği işlem riski üzerinde durulacaktır.

Döviz riski, yabancı bir para birimi üzerinden mal ya da hizmet satın alındığında, alım işleminin gerçekleştiği gün ile ödemenin yapılacağı vade arasında ortaya çıkmaktadır (Kaygusuz, 1998:7). Bu çerçevede işlem riski, döviz kurlarındaki dalgalanmaların, mal ve hizmet satın alımlarından kaynaklanan nakit hareketlerini ve böylelikle kar/zarar hesap tutarlarını etkilemesi riskidir (Redhead ve Hughes, 1988:3).

Türev ürünlerin kullanımının 1990’lı yıllarda uluslararası piyasalarda ve özellikle ABD'de artması ile birlikte türev ürünlerin muhasebesi ile ilgili çalışmalar artış göstermiştir. UMSK (Uluslararası Muhasebe Standartları Kurulu) tarafından yürütülen çalışmalar neticesinde 2001 yılında "Finansal Araçlar: Muhasebeleştirilme ve Ölçüm” adını taşıyan UMS 39 yayınlanmıştır.

UMS 39 ile bir işletmenin finansal tablolarında; finansal araçlar hakkında kayda alma, değerleme ve açıklanacak bilgiler konusundaki ilkeleri oluşturmak amaçlanmıştır (Akgül ve Akay, 2003:191).

Tenker (2004) "IAS 39 Uygulamalarının Düşündürdükleri” ile Haftacı ve Pehlivanlı (2007) “UMS 39 ve Uygulamada Karşılaşılan Sorunlar” başlıklı makalelerde UMS 39'a göre 
türev ürünlerin muhasebeleştirilmesi ile ilgili düzenlemeler ve esaslar teorik bir çerçevede incelenmiştir.

Kaygusuz (1998) "Finansal Türev Ürünlerinde Muhasebe Esasları" ile Örten ve Örten (2001) “Türev Finansal Araçlar ve Muhasebe Uygulamaları” adlı kitaplarda, türev ürünlerin muhasebeleştirilmesi ile ilgili örnek uygulamalar yer almaktadır.

Yine Uzun tarafından 2004 y1lında yayımlanan “Türkiye'deki Uygulamalar, 39 Numaralı Muhasebe Standartları ve Avrupa Merkez Bankası Uygulamaları Çerçevesinde Türev Ürünlerin Muhasebeleştirilmesi ve Finansal Tablolara Yansıması" başlıklı uzmanlık yeterlilik tezinde türev ürünlerin uygulaması ile ilgili çok sayıda örnek yer almaktadır.

Bline, Fischer ve Skekel (2004) “Advanced Accounting” adlı kitapta, türev ürünlerle ilgili örnek muhasebe kayıtları yer almaktadır.

$\mathrm{Bu}$ çalışmada döviz opsiyon sözleşmeleri hakkında teorik bilgiler sunulmaktadır. Ardından ödemeyi yabancı para cinsinden ileri bir tarihte yapmak üzere yabancı bir ülkeden mal alışı yapan yerli bir işletmenin, kur riskinden korunmak üzere döviz alım opsiyon sözleşmesi satın alması ve ödeme günü geldiğinde döviz opsiyon sözleşmesi çerçevesinde alım hakkını kullanması ile ilgili muhasebe kayıtlarına yer verilmektedir.

\section{OPSIYYN SÖZLEŞMELERİ}

Opsiyon sözleşmeleri, vadeli işlem piyasalarında kullanılan araçlardan bir tanesidir. Vadeli işlem piyasaları, ileri bir tarihte teslimatı veya nakit uzlaşması yapılmak üzere herhangi bir malın veya finansal aracın, bugünden alım satımının yapıldığı piyasalardır. Vadeli işlem piyasalarında sıklıkla dört tip riskten korunma aracı kullanılmaktadır. Bunlar Forward, Future, Opsiyon ve Swap sözleşmeleridir (Usta,2002:224 ; Karaca, Hacıhasanoğlu ve Demirci,2014:248).

Opsiyon sözleşmeleri, miktarı ya da tutarı bugünden belirlenmiş bir finansal aracın belirlenen bir tarihte ve belirlenmiş bir fiyat üzerinden satın alınması veya satılması üzerine yapılmış sözleşme olarak ifade edilebilir. Opsiyon sözleşmelerinde, sözleşmenin taraflarından birine sözleşmedeki hakları kullanmak ya da bu haklardan vazgeçmek hakkı tanınırken, diğer tarafa sözleşmenin gereklerini yerine getirme sorumluluğu yüklenmektedir (Uzun, 2004:96). $\mathrm{Bu}$ anlamda opsiyon sözleşmelerinin, future ve forward gibi diğer vadeli işlem sözleşmelerinden farkı alıcıya bir hak sağlayıp, alıcıyı ürünün alımı veya satımı konusunda herhangi bir yükümlülük altında bırakmamasıdır (Ocakoğlu,2013:51).

Opsiyon sözleşmeleri çeşitli açılardan sınıflandırmak mümkün olmakla birlikte temel olarak alım opsiyonu (Call Options) ve satım opsiyonu (Put Options) şeklinde sinıflandırılabilir.

Alım opsiyonu, gelecekteki belirli bir tarihte veya bu tarihten önce, belirlenmiş bir fiyat üzerinden alıcısına satın alma hakkı veren bir sözleşmedir (Bookstaber, 1987:1; Dubofsky, 1992:11). Burada dikkat edilmesi gereken nokta, alıcı satın alma hakkını kullanıp 
kullanmamakta özgürdür. Yani alım opsiyonunu kullanma hakkı, tek taraflı olarak satın alma opsiyonunu alana aittir. Ancak sözleşmenin karşı tarafı, alıcı satın alma hakkını kullanmak istediğinde, sözleşme ile yükümlüdür.

Satım opsiyonu ise opsiyon alıcına sözleşmeye konu olan varlıkları belirli bir tarihte veya belirli bir tarihe kadar opsiyon sözleşmesinde belirlenmiş olan fiyattan satma hakk1 taniyan opsiyondur (Bak,2009:49). Burada da dikkat edilmesi gereken nokta, opsiyonun alıcısı satma hakkını kullanıp kullanmamakta özgürdür. Yani satım opsiyonunu kullanma hakkı, tek taraflı olarak satın alma opsiyonunun alıcısına aittir. Ancak sözleşmenin karşı tarafı, satıcı satma hakkını kullandığında, sözleşme ile yükümlüdür.

Her iki opsiyon türünde de sözleşmenin taraflarından biri için bir hakkın kullanımı, diğer taraf için ise bir yükümlülügün yerine getirilmesi söz konusudur. Satın alma opsiyonunda opsiyon alıcısı opsiyonu kullanmaya karar verdiğinde, opsiyonun satıcısı, sözleşmeye konu varlığı belirlenen fiyattan satmak zorundadır. Aynı şekilde satım opsiyonunda, opsiyon sahibi opsiyonu kullandığında, satıcı sözleşmeye konu varlı̆̆ belirlenen fiyattan satın almak zorundadır (Önce, 1995:35).

Bununla birlikte her iki sözleşme türünü birbirinden ayıran en temel faktör yatırımcıların beklentisidir. Üzerine sözleşme yazılan varlık ya da menkul kıymetin fiyatının gelecekte yükseleceği beklentisine sahip yatırımcı "alım opsiyonu" satın alırken, fiyatların gelecekte düşeceği beklentisine sahip yatırımcı ise "satım opsiyonu" satın almaktadır (Çelik,2012:12). Aşağıdaki şekilde alım ve satım opsiyonları özet halinde yer almaktadır.

Opsiyona Dayanak Teşkil

Eden Varlığ Kullanım

Fiyatı Karşılığında Satın

Alma Hakkına Sahiptir

\author{
Opsiyona Dayanak Teşkil \\ Eden Varlığı Kullanım Fiyatı \\ Karşılığında Satma Hakkına \\ Sahiptir
}

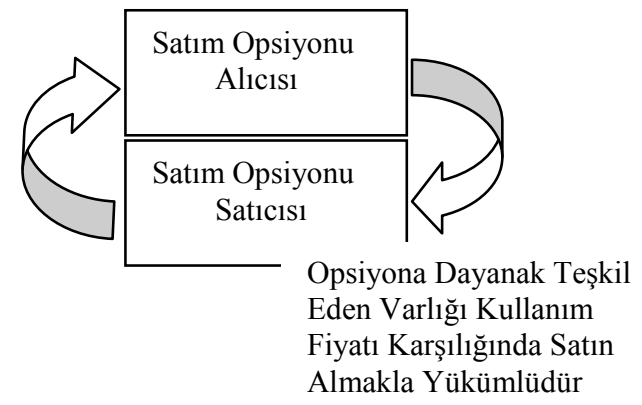

Şekil 1: Alım Opsiyonu - Satım Opsiyonu

Kaynak: Türev Araçlar Lisanslama Rehberi, 2006:224 
Opsiyon (Alım-Satım) sözleşmelerinin uygulama sürecinde iki farklı uygulama vardır. Bunlar:

- Amerikan Opsiyonu

- Avrupa Opsiyonu

İki yöntem arasındaki farklılık, opsiyon sözleşmelerinin uygulamaya konma sürelerinden kaynaklanmaktadır.

Amerikan yönteminde, opsiyon belirlenen tarihte veya bu tarihten önce uygulamaya konulabilmektedir. Avrupa yönteminde ise, opsiyon sözleşmesi sadece belirlenen tarihte uygulanabilmektedir (Dubofsky, 1992:11-14; Marshall ve Bansal, 1992:339).

Alım opsiyonu söz konusu olduğunda; Amerikan yönteminde alıcı, satın alma hakkını sözleşmede belirlenen tarihte veya bu tarihten önce kullanabilirken, Avrupa yönteminde alıc1, satın alma hakkını ancak sözleşmede belirlenen tarihte kullanabilmektedir.

Satım opsiyonu söz konusu olduğunda; Amerikan yönteminde satım opsiyonunun alıcısı, satım hakkını belirlenen tarihte veya bu tarihten önce kullanırken, Avrupa yönteminde satım opsiyonu ancak sözleşmede belirlenen tarihte gerçekleştirilebilmektedir.

\subsection{Döviz Opsiyon Sözleşmeleri}

Döviz opsiyonları ilk kez Aralık 1982'de "Philadelphia Stock Exchange (PHLX)" 'de işlem görmeye başlamış olup bunu "Chicago Board of Options Exchange (CBOE)" ve United "Currency Options Market (CBOE)" borsalarının faaliyetleri izlemiştir (Kurtay, 1997:89,90). Bunların yanı sıra tezgah üstü piyasalarda da döviz opsiyonu işlemlerinin yapıldığı gözlenmiştir.

Belirli bir yabancı parayı belirli bir fiyattan (ulusal para olarak), öngörülen sürede satın alma hakkı doğuran (zorunluluğu değil) sözleşmeler döviz alış opsiyonu (call option) adı verilmektedir. Tersi durumda, bir yabancı parayı sabit fiyattan belirli bir sürede satma hakkı veren sözleşmelere de döviz satış opsiyonu (put option) denmektedir (Seyidoğlu, 1997:113).

İlk kez 1982 yılında Philadelphia Borsasında işlem gören döviz opsiyonları, 1984 yılında Chicago Borsası'nda işlem görmeye başlamış olup işlem hacmi giderek artmıştır (Melvin, 1989:79).

Bank for International Settlement -BIS tarafindan üçer yıllık dönemler itibariyle yürütülen çalışmaların bir ürünü olarak ortaya çıkan, dünya çapındaki döviz işlemlerinin finansal araçlar itibari ile gösterdiği eğilim ve dağılım aşağıdaki tabloda gözlenmektedir. 
Tablo 1:Küresel Döviz Piyasası İşlemlerinin Araç Türlerine Göre Dağılım (Nisan ayı günlük ortalamaları, milyar dolar cinsinden)

\begin{tabular}{|l|r|r|r|r|r|}
\hline & \multicolumn{1}{|c|}{1998} & \multicolumn{1}{|c|}{2001} & \multicolumn{1}{c|}{2004} & \multicolumn{1}{c|}{2007} & \multicolumn{1}{c|}{2010} \\
\hline Döviz işleminin türü & 1,527 & 1,239 & 1,934 & 3,324 & 3,981 \\
\hline Spot İşlemler & 568 & 386 & 631 & 1,005 & 1,490 \\
\hline Forward (Alivre) İşlemler & 128 & 130 & 209 & 362 & 475 \\
\hline $\begin{array}{l}\text { Yabancı Para (Döviz) } \\
\text { Swapları }\end{array}$ & 744 & 663 & 975 & 1,745 & 1,808 \\
\hline Opsiyonlar ve Diğer ürünler & 87 & 60 & 119 & 212 & 207 \\
\hline
\end{tabular}

Kaynak: http://www.bis.org/publ/rpfxf10t.pdf, 03.5.2014

Tablodan da görüldüğü üzere döviz işlemlerinin hacminde, küresel krizin etkilerinin görüldüğü 2001 yılı dışarıda tutulduğunda, yıllar itibariyle kararlı ve artan oranlı bir artış gözlenmektedir. Türkiye'deki finansal türev ürün sözleşmelerinin zaman içinde gösterdiği eğilime bakıldığında ise, gerek sözleşme sayısı gerekse sözleşme değeri açısından sürekli bir artış vardır. Bu durum aşağıda yer alan Tablo 2'de gözlenmektedir.

Tablo 2: Türkiye'deki Finansal Türev Ürün Sözleşeme Sayıları ve Değerleri

\begin{tabular}{|c|l|l|l|l|l|}
\hline & 2005 & 2006 & 2007 & 2008 & 2009 \\
\hline $\begin{array}{c}\text { Finansal } \\
\text { Türev } \\
\text { Ürün SayıS1 } \\
\text { (Bin Adet) }\end{array}$ & $1,832.5$ & $6,846.7$ & $24,866.9$ & $54,445.7$ & $79,313.0$ \\
\hline $\begin{array}{c}\text { Finansal } \\
\text { Türev } \\
\text { Üün Değeri } \\
\text { (Milyon TL) }\end{array}$ & 3.029 & 17.872 & 118.035 & 207.863 & 333.580 \\
\hline
\end{tabular}

Kaynak: http://www.bis.org/publ/cpss95.pdf, 3.5.2014

Genel olarak döviz opsiyon sözleşmeleri, gelecekteki belirli bir tarihte veya bu tarih süresince, bugünden belirlenmiş bir fiyat üzerinden, bir dövizin satın alma hakkını ya da satma hakkını satın almaktır. Bu hakkı kullanıp kullanmama kararı tek taraflı olarak sözleşmeyi satın alana aittir. Alıcı, sözleşmede belirlenen süredeki durumun lehine olması halinde satın alma ya da satma hakkını kullanırken, aleyhinde olması durumunda bu hakkını kullanmayacaktır. Sözleşmedeki alıcı taraf sözleşmeyi yerine getirmek istediğinde, satıcı tarafın herhangi bir tercih hakkı yoktur ve sözleşme şartlarını yerine getirmekle yükümlüdür.

Opsiyon sözleşmesinin alıcı tarafı, sözleşmeden doğan hakkını kullanıp kullanmamaya, vade tarihindeki kur ile sözleşmede belirtilen kuru karşılaştırmak suretiyle, opsiyonun karda ya da zararda olma durumuna göre karar verecektir. Optimal olan durum, alım ya da satım sözleşmesini alan tarafın kararı; sözleşme karda ise alım ya da satım hakkını kullanmak, zararda ise kullanmamak yönünde olacaktır. Opsiyon sözleşmesinin kar, zarar ya da başabaş noktasında olma durumları aşağıdaki tablo yardımı ile gözlenebilmektedir: 
Tablo 3: Opsiyon Sözleşmesinin Kar-Zarar-Başabaş Durumları

\begin{tabular}{|c|c|c|}
\hline Kar - Zarar - Başabaş & $\begin{array}{l}\text { Alım Opsiyonu } \\
\text { (Call) }\end{array}$ & $\begin{array}{c}\text { Satım Opsiyonu } \\
\text { (Put) }\end{array}$ \\
\hline $\begin{array}{l}\text { Kar Durumundaki } \\
\text { Opsiyon }\end{array}$ & $\begin{array}{l}\text { Cari Kur > Söz. } \\
\text { Kur }\end{array}$ & $\begin{array}{l}\text { Cari Kur < Söz. } \\
\text { Kur }\end{array}$ \\
\hline $\begin{array}{l}\text { Zarar Durumundaki } \\
\text { Opsiyon }\end{array}$ & $\begin{array}{l}\text { Cari Kur < Söz. } \\
\text { Kur }\end{array}$ & $\begin{array}{l}\text { Cari Kur > Söz. } \\
\text { Kur }\end{array}$ \\
\hline $\begin{array}{l}\text { Başabaş Durumundaki } \\
\text { Opsiyon }\end{array}$ & $\begin{array}{l}\text { Cari Kur } \cong \text { Söz. } \\
\text { Kur }\end{array}$ & $\begin{array}{l}\text { Cari Kur } \cong \text { Söz. } \\
\text { Kur }\end{array}$ \\
\hline
\end{tabular}

\subsection{Opsiyon Primi}

Opsiyon sözleşmesi ile tek taraflı bir hak edinmiş olan alıcı, yükümlülük altına girerek risk alan opsiyon satıcısına, katlandığı riske karşı1ık belli bir tutar prim ödemek zorundadır. $\mathrm{Bu}$ anlamda opsiyon primi, opsiyon sözleşmesi ile sağlanan alım ve satım hakkı karşılığında alıcının satıcıya ödediği fiyattır. Diğer bir ifadeyle satıcının sözleşmeyi düzenlemekle opsiyon dönemi boyunca karışılacağı riske karşın talep ettiği bedeldir (Akkum,2000:49). Satıcı, sözleşmenin yapıldığı tarihte almış olduğu prim karşıllğında sözleşmeyi yerine getirme yükümlülüğü altına girmiş olduğundan, alıcı opsiyon hakkını kullansın kullanmasın almış olduğu opsiyon primini geri ödemeyecektir.

Opsiyon sözleşmelerindeki alıcı tarafın tek kaybı, kendisine tanınan opsiyon hakkını kullanmaması durumunda ödemiş olduğu primle sınırlı iken, alıcı teorik de olsa sınırsız bir gelir elde etme imkanına sahiptir. Diğer taraftan, opsiyon sözleşmesindeki satıcı tarafın geliri opsiyon primi ile sınırlı olmakta, buna karşılık teorik de olsa sınırsız bir zarar riskine katlanmak durumunda kalmaktadır. Opsiyon primi, Avrupa opsiyonunda vade sonuna, Amerikan opsiyonunda işlemin sonuçlandırılacağı tarihe kadar satıcının vermiş olduğu fiyat garantisinin maliyetini oluşturur ve zararına neden olduğu takdirde alıcıya mukavele hükmünü yerine getirmeme (cayma) hakkını verir (Örten ve Örten, 2001:251).

\section{TMS 39/TFRS 9 VE TÜRKIYE'DEKİ DURUM}

Yıllardır dünyada ve paralel olarak ülkemizde, işletmelerde gerçekleşen ticari ve finansal işlemlerin muhasebeleştirilmesi ve raporlanmasında belirli bir standardı sağlamak, karşılaştırılabilirlik ve anlamlılık düzeyini arttırmak çabalarının ürünü olarak bir dizi standart yayınlanmaktadır. Çeşitli mesleki kuruluşlar tarafından farklı adlar altında yayınlanan standartlar anlam karmaşasına yol açmaktadır. Bunun önüne geçebilmek için standartlar ile ilgili -Dünya'da ve Türkiye'de gerçekleştirilen- çalışmaları aşağıdaki tablo yardımı ile gözlemlemek mümkündür. 
Tablo 4: Dünya'da ve Türkiye'de Muhasebe Standartları ile İlgili Yapılan Çalışmalar

\begin{tabular}{|c|c|c|c|c|}
\hline Periyot & $\begin{array}{l}\text { Küresel } \\
\text { Düzenleyici } \\
\text { Otorite }\end{array}$ & $\begin{array}{c}\text { Küresel } \\
\text { Düzenleme }\end{array}$ & $\begin{array}{c}\text { Türkiye } \\
\text { Düzenleyici } \\
\text { Otorite }\end{array}$ & $\begin{array}{c}\text { Türkiye } \\
\text { Düzenleme }\end{array}$ \\
\hline $\begin{array}{l}1973- \\
2001\end{array}$ & $\begin{array}{l}\text { Uluslararas1 } \\
\text { Muhasebe } \\
\text { Standartlar1 } \\
\text { Komitesi } \\
\text { (IASC) }\end{array}$ & $\begin{array}{l}\text { Uluslararas1 } \\
\text { Muhasebe } \\
\text { Standartlar1 } \\
\text { (IAS) }\end{array}$ & $\begin{array}{c}\text { TMUD } \\
\text { TMUDESK }\end{array}$ & $\begin{array}{c}\text { Türkiye } \\
\text { Muhasebe } \\
\text { Standartları } \\
\text { (TMS) }\end{array}$ \\
\hline $\begin{array}{l}2001- \\
\ldots \ldots .\end{array}$ & $\begin{array}{c}\text { Uluslararas1 } \\
\text { Muhasebe } \\
\text { Standartları } \\
\text { Kurulu } \\
\text { (IASB) }\end{array}$ & $\begin{array}{c}\text { Uluslar } \\
\text { aras1 } \\
\text { Finansal } \\
\text { Raporlama } \\
\text { Standartları } \\
\text { (IFRS) }\end{array}$ & $\begin{array}{c}\text { TMSK } \\
\text { KGK }\end{array}$ & $\begin{array}{c}\text { Türkiye } \\
\text { Finansal } \\
\text { Raporlama } \\
\text { Standartları } \\
\text { (TFRS) }\end{array}$ \\
\hline
\end{tabular}

Uluslararası Muhasebe Standartları Komitesi (IASC), kurulduğu 1973 y1lından 2001 yılına kadar, uluslararası düzeyde muhasebe standartları oluşturmuş ve yayınlamıştır. 2001 yılında, etkinliğin arttırılması ve kapsamın genişletilmesi amacıyla, Uluslararası Muhasebe Standartları Kurulu (IASB) kurulmuş olup, komite, standart oluşturma, yayınlama görev ve yetkisini bu kurula devretmiştir (Akbulut vd., 2011:7). Bu çerçevede:

- Uluslararası Muhasebe Standartları Komitesi tarafından yayınlanmış standartlar UMS (IAS) koduyla,

- Uluslararası Muhasebe Standartları Kurulu tarafından yayınlanmış standartlar UFRS (IFRS) koduyla anılmaktadır.

Uluslararası platformda yerleşmiş olan bu kabule paralel olarak Türkiye Muhasebe Standartları Kurulu (TMSK) da, UMS ve UFRS'leri Türkiye Muhasebe Standartları (TMS) ve Türkiye Finansal Raporlama Standartları (TFRS) olarak yayınlamıştır (Akbulut vd., 2011:7). 2 Kasım 2011 tarihli 660 Sayılı Kanun Hükmünde Kararname ile TMSK kapatılmış ve yerine "Kamu Gözetimi Muhasebe ve Denetim Standartları Kurumu (KGK)" adı altında yeni bir kurum oluşturulmuştur. Bu tarihten itibaren TMSK tarafından yürütülmekte olan çalışmalar yeni kuruma (KGK) devredilmiştir.

Haziran 2013 itibariyle finansal araçların ölçülmesi ve muhasebeleştirilmesi halen yürürlükte bulunan "TMS 39:Finansal Araçlar: Muhasebeleştirme ve Ölçme” standardına göre yapılabileceği gibi 1 Ocak 2015 tarihinde TMS 39'un yerine geçecek olan “TFRS 9: Finansal Araçlar" standardına göre de yapılabilmektedir. Finansal araçların değerlendirilmesinde kullanılan önemli ölçütlerden biri olan gerçeğe uygun değer hesaplamaları ile ilgili olarak da “TFRS 13 Gerçeğe Uygun Değer Ölçümü” standardı yol gösterici olmaktadır (Şavlı, 2014:63).

Bu çalışmanın kapsamı açısından adı geçen standartlardan "TMS 39:Finansal Araçlar: Muhasebeleştirme ve Ölçme" standardı ve "TFRS 9: Finansal Araçlar" standardında türev 
ürünler, bunların sınıflandırılması ve muhasebeleştirilmesi ile ilgili düzenlemeler yer almaktadir.

TMS 39; türev ürün sözleşmelerinin kayıtlara alınması, kayıtlardan çıkarılması ve sözleşme vadesi süresince gerçekleştirilen değerleme kriterleri noktalarında muhasebeleştirilmesi ve mali raporlarda gösterilmesi ile ilgili hükümleri içermektedir.

TMS 39' m.4'de, “işletme, bir finansal borcu, sadece ve sadece, ilgili finansal aracin sözleşmeye bağlı koşullarına taraf olduğu durumlarda bilançosuna yansıtır" denmek suretiyle türev ürün sözleşmelerinin bilançoda raporlanacağı belirtilmektedir.

Selvi ve diğerleri (2007) tarafından, İMKB-100 endeksinde yer alan ve reel sektörde faaliyet gösteren 79 şirketin 31.12.2006 tarihli konsolide finansal tablo dipnotları üzerinde gerçekleştirilen bir araştırmada, 28 şirketin türev ürün sözleşmesi kullandığı tespit edilmiştir.

Aynı çalışmada türev ürün sözleşmesi kullanan şirketlerin sadece dokuzunun "riskten korunma muhasebesi”ne göre raporlama yaptıkları gözlenmiştir. Şirketlerin, TMS 39'da yer alan "Riskten Korunma Muhasebesi" için gerekli kriterlerin yerine getirilmesinde zorluk çektikleri ve bu yüzden "Riskten Korunma Muhasebesi"ne göre raporlama yapmadıkları saptanmıştır (Selvi vd, 2007:240-243). Sadece Türkiye açısından değil, diğer birçok ülke açısından da TMS 39 kriterlerinin sağlanmasında katlanılması gereken bir dizi zorluk ve maliyetin bulunduğu belirtilmektedir (Healy, 2004:18).

TMS 39'da türev ürün tanımı aşağıda yer alan üç özelliğin tamamına sahip olan ve bu standart kapsamında bulunan bir finansal araç veya diğer bir sözleşmedir şeklinde yapılmıştır (TMSK, 2010:816-817):

- $\quad$ Belirli bir faiz oranında, finansal araç fiyatında, mal bedelinde, döviz kurunda, fiyat veya oran endeksinde, kredi derecesi veya kredi endeksinde ya da başka bir değişkende veya sözleşmenin taraflarından birine özgü olmayan finansal olmayan bir değişkende meydana gelen bir değişkenlik karşısında değeri değişmektedir.

- Net bir başlangıç yatırımı gerektirmemekte veya piyasa koşullarındaki değişikliklere benzer tepki vermesi beklenen diğer türden sözleşmelere göre daha az bir net başlangıç yatırımı gerektirmektedir ve

- $\quad$ Gelecek bir tarihte ödenecektir.

Finansal riskten korunma muhasebesinde, finansal riskten korunma aracı ile finansal riskten korunma konusu kalemin gerçeğe uygun değerlerinde meydan gelen değişikliklerin kar veya zarardaki etkileri muhasebeleştirilir (TMSK, 2010:840).

Finansal riskten korunma aracı ile finansal riskten korunma konusu kaleme ilişkin kazanç veya kaybın muhasebeleştirilmesinde (TMSK, 2010:841-842);

- Finansal riskten korunma aracının gerçeğe uygun değerinin yeniden ölçülmesinden veya söz konusu finansal riskten korunma aracının defter değerine ilişkin 
yabancı para bileşeninin ölçülmesinden kaynaklanan kazanç veya kayıplar, kar ya da zararda muhasebeleştirilir ve

- Finansal riskten korunma konusu kalemden kaynaklanan ve korunulan riskle ilişkilendirilebilen kazanç veya kayıp, finansal riskten korunma konusu kalemin defter değerine yansitılır ve kar veya zararda muhasebeleştirilir.

Şeklinde ifade edilen maddelerde, finansal riskten korunma aracının değerinde zaman içinde meydan gelen artış ya da azalışların, gerek ilgili finansal aracın kaydedildiği hesaplarda gerekse kar/zarar hesaplarında gösterilme gerekliliği vurgulanmıştır.

İşletme TMSK (2010:842)'ye göre;

- Finansal riskten korunma aracinın vadesinin dolması, satılması, sona erdirilmesi veya kullanılması,

- $\quad$ Finansal riskten korunma işleminin gerekli koşulları sağlayamaz duruma gelmesi veya

- İşletmenin ilgili işleme ilişkin sınıflandırmayı/düzenlemeyi iptal etmesi, durumlarından birinin oluşması halinde finansal riskten korunma muhasebesini uygulamaya son verir.

TMS 39 zamanla TFRS 9'a dönüşmüştür. Her iki standart da finansal varlıkları, bu varlıkların özelliklerine göre sinıflandırmakta ve gruplandırmaktadır. Ancak TMS 39'da oldukça karmaşık olan sınıflandırma, TFRS 9'da büyük ölçüde sadeleştirilmiş olup 2013'den itibaren, TFRS' de yer alan basit ve sade gruplandırma esas alınacaktır (Akbulut vd, 2011:1719).

- $\quad$ TFRS 9'a göre bütün finansal araçların (varlık ve yükümlülükler) ilk muhasebeleştirilmelerinde "gerçeğe uygun değer" esas alınacaktır.

- $\quad$ Finansal araçların sonraki değerlemelerinin ölçüsü de, bunların elde bulundurulma niyetine ve nakit akışı özelliklerine göre ya gerçeğe uygun değer ya da itfa edilmiş maliyet bedeli olmaktadır.

İlgili standartlara getirilen en büyük eleştiri, standartların birden fazla alternatif uygulamaya yer vermesidir. Alternatif muhasebeleştirme teknikleri finansal tabloların karşılaştırılabilirliğini olumsuz etkilemekte ve bunun sonucunda da, finansal tablolara bakarak karar alacak olan kişi ve kurumları yanlış yönlendirmektedir (Haftacı ve Pehlivanlı, 2007:146).

Kamu Gözetimi Muhasebe ve Denetim Kurumu tarafından alınan karar çerçevesinde hazırlanan Bakanlar Kurulu Kararı ile belirlenen ve zamanla yenilenen nitelik ve ölçeklere sahip işletmeler 1 Ocak 2013 tarihli muhasebe döneminden itibaren finansal raporlamalarını Türkiye Finansal Raporlama Standartlarına göre yapmaktadırlar. Muhasebe kayıtları VUK uyumlu olarak yapılmaya devam edilmekte ancak finansal raporlar TFRS uyumlu olmaktadır.. 


\section{4. ÖRNEK UYGULAMA}

Döviz alım opsiyon sözleşmesi satın alınması işlemi; kurlardaki değişiklikler karşısında değerinin değişmesi, sözleşmenin yapıldığı tarihte “opsiyon primi” şeklinde nispeten sözleşmedeki tutardan daha az bir net başlangıç yatırımına yol açması ve daha sonraki bir tarihte ödenmesi yönüyle TMS 39'da yapılan türev ürün tanımlamasındaki üç unsuru da karşılamaktadır

Aşağıdaki örneğin oluşturulmasında ve muhasebeleştirilmesinde Bline vd. (2004) referans alınmıştır.

Ayrıca hesap kodlarının ve hesap isimlerinin belirlenmesinde, bir öneri olarak, TMSK tarafından hazırlanmış daha sonra geri çekilmiş olan TMS/TFRS uyumlu hesap planı taslağı kullanılmıştır. Henüz uygulama bütünlüğünü sağlayacak, muhasebe ve finansal raporlama standartları ile uyumlu bir hesap planı yayımlanmamıştır. Bu duruma işaret etmek amacıyla örnekteki yevmiye kayıtlarında geri çekilen taslaktaki hesap isimleri ve kodları kullanılmıştır. Muhasebe kayıtları sadece mal alışını yapan alıcı (döviz alım opsiyon sözleşmesini alan) taraf için yapılmıştır. Mal satışını yapan işletme, döviz opsiyon sözleşmesinde taraf olmadığ için satıcının yapacağı muhasebe kayıtlarına yer verilmemişstir.

Türkiye "A" işletmesi, Almanya "B" işletmesinden 17.10.2013 tarihinde 10.000 birim ticari malı, 10 EURO birim fiyat üzerinden satın almış olup aynı tarihte mal teslimatı gerçekleştirilmiştir. Ticarete konu mallara ilişkin ödeme 19 Mart 2014 tarihinde EURO cinsinden gerçekleştirilecektir. Teslimatın yapıldığı 17.10.2013 tarihinde 1 EURO=2,7543 TL'dir. Türkiye “A” işletmesi ödemeyi gerçekleştireceği 19.03.2014 tarihinde EURO kurunun daha yüksek bir düzeyde seyredeceğini öngörmekte ve muhtemel kur riskinden korunmak istemektedir. $\mathrm{Bu}$ bağlamda 17.10.2013 tarihinde bir arac1 kurumdan 1 $E U R O=2,8599$ TL sözleşme fiyatı üzerinden bir döviz alım opsiyon sözleşmesi satın almıştır. Sözleşme gereği opsiyon sözleşmesinin değerini temsil eden 3.200 TL opsiyon primi ödemiştir.

Teslimatın ve sözleşmenin yapıldığı 17.10.2013, bilanço tarihi olan 31.12 .2013 ve ödemenin yapıldığı 19.03.2014 tarihlerindeki döviz kurları, hesap bakiyeleri ve opsiyon sözleşmesi değerleri aşağıdaki tablodaki gibi gerçekleşmiştir:

\begin{tabular}{|c|c|c|c|}
\hline Tarih & $\begin{array}{c}\text { Cari } \\
\text { Kur } \\
(\mathrm{TL})\end{array}$ & $\begin{array}{c}\text { Satıcılar Hesap } \\
\text { Bakiyesi } \\
(10.000 * 10 * \text { Cari Kur })\end{array}$ & $\begin{array}{c}\text { Opsiyon } \\
\text { Sözleşmesi } \\
\text { Değeri (TL)* }\end{array}$ \\
\hline 17.10 .2013 & 2,7543 & 275.430 & 3.200 \\
\hline 31.12 .2013 & 2,9753 & 297.530 & 12.630 \\
\hline 19.03 .2014 & 2,9442 & 294.420 & 8.430 \\
\hline
\end{tabular}

* Opsiyon sözleşmesi değeri (fair value-makul değer); ilgili tarihteki kurlar, vadeye kadar kalan süre, faizlerdeki değişimler, dalgalanmalar ve diğer opsiyonların anlaşma 
fiyatlarının etkisi altında belirlenmektedir ve opsiyon sözleşmesinin gerçeğe uygun değerini yansıtmaktadır. Örnekte bu değerler veri olarak bulunmaktadır. $\mathrm{Bu}$ verilerin hesaplanması oldukça karmaşık hesaplamalar içermektedir ve çalışmanın kapsamı gereği bu hesaplamalara yer verilmemiştir.

Muhasebe kayıtlarına geçmeden önce Türkiye "A" işletmesinin opsiyon sözleşmesi satın almak suretiyle sabitlenmiş olan borcu aşağıdaki şekilde hesaplanabilir:

[10.000 br. * 10 EURO * Kullanım Fiyatı(Sözleşmedeki Kur)] + Ops.

Sözleşmesi Değeri

$(10.000 * 10 * 2,8599)+3.200=289.190 \mathrm{TL}$

Yukarıdaki hesaplamada görüldüğ̈̈ üzere Türkiye "A" işletmesi döviz alım opsiyonu satın almak suretiyle 19.03.2014 tarihinde yapacağı 100.000 EURO tutarındaki ödemeyi 285.990 TL ile sabitlemiş durumdadır. Böylece işletme ödeme tarihindeki kurun çok yüksek seviyelerde olma riskinden kurtulmuş olacaktır. İşlemlerin muhasebe kayıtları aşağıda yer almaktadır. Muhasebe kayıtları, TMSK No:2 Tekdüzen Hesap Planı Uygulama Genel Tebliği ile belirlenmiş olan taslak hesap planı çerçevesinde oluşturulmuştur.

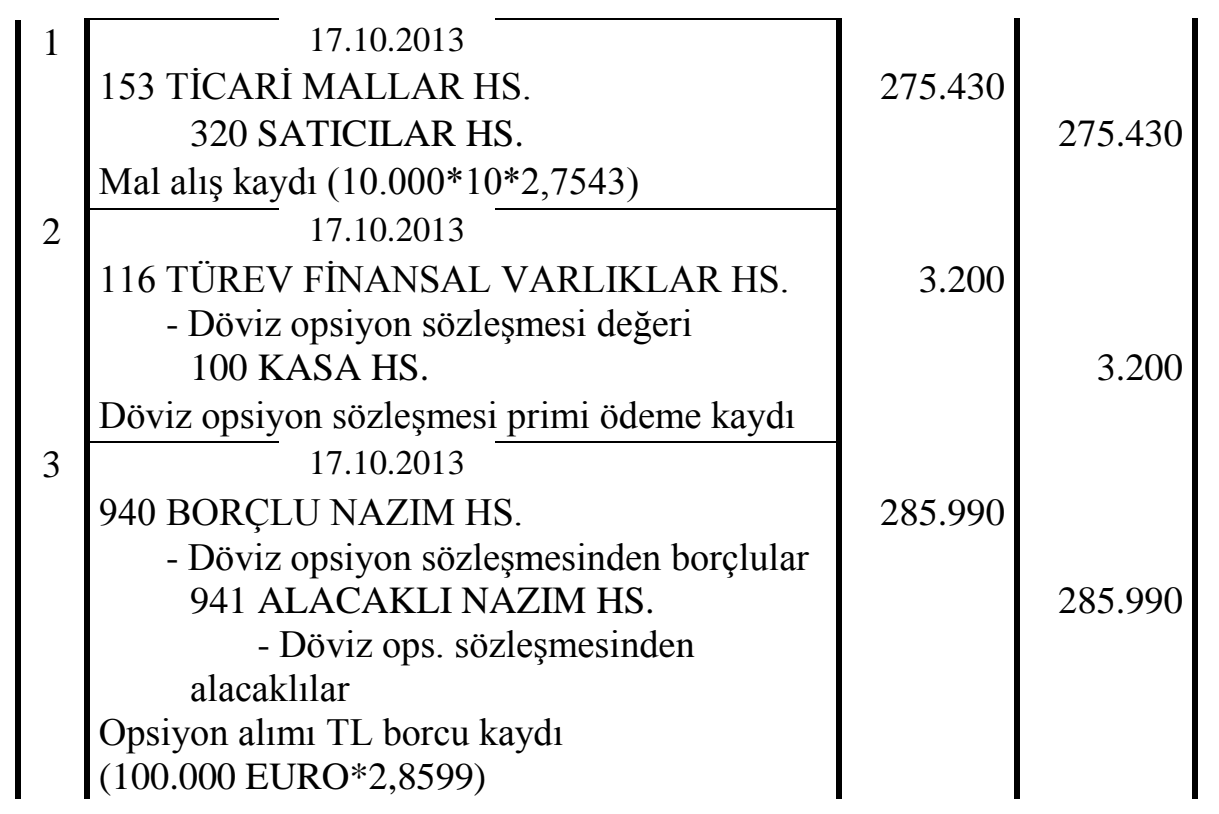

17.10.2013 tarihinde ticari malların teslim alınıp 153 Ticari Mallar stok hesabına kaydedilmesi, Almanya "B" firmasına olan borcun o günkü kur üzerinden 320 Satıcılar hesabına kaydedilmesi, döviz opsiyon sözleşmesi priminin ödenmesi ve opsiyon sözleşmesi değerinin 116 Türev Finansal Varlıklar hesabına kaydedilmesi ile satın alınan opsiyonun TL karşılığı tutarının nazım hesaplarda izlenmesine ilişkin kayıtlar yukarıdaki yevmiye maddelerinde yer almaktadır. 
TMSK tarafından hazırlanan taslak değil de mevcut Tekdüzen Hesap Planına göre kayıtlar yapılsaydı döviz opsiyon sözleşmesi değeri 118 Diğer Menkul Kıymetler Hesabına kaydedilecekti.

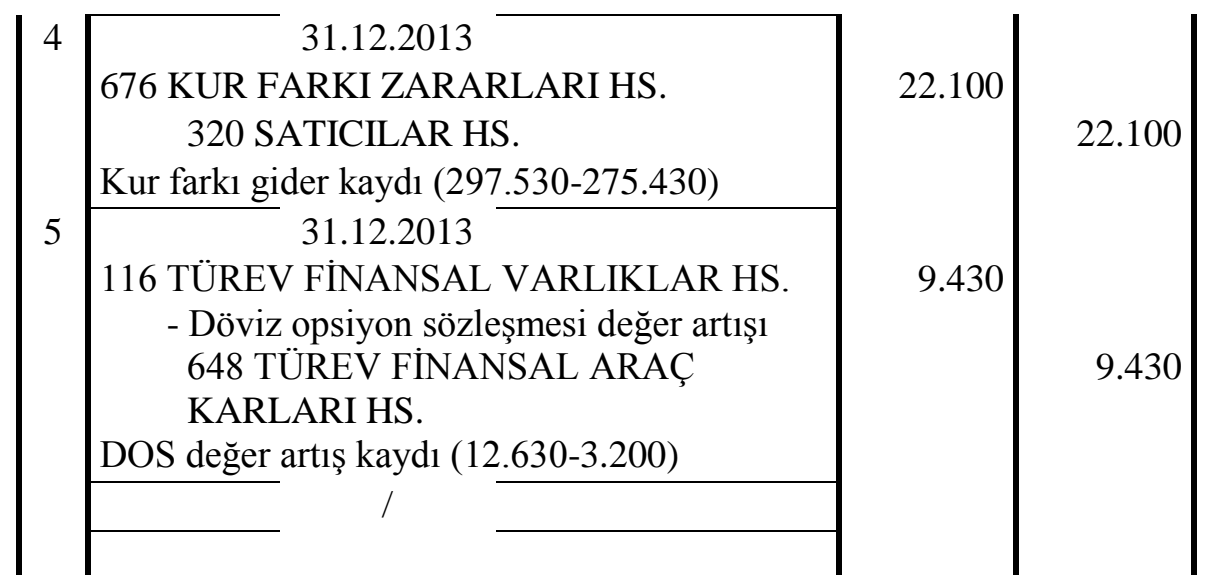

Türkiye "A" işletmesinin bilanço tarihi olan 31.12.2013 tarihindeki döviz kurundaki artıştan dolayı satıcılara olan borcun artması ve maruz kalınan kur zararının 676 Kur Farkı Zararları hesabına kaydedilmesine ilişkin kayıtlar yukarıda yer almaktadır. Ayrıca 31.12.2013 tarihinde Opsiyon sözleşmesinin değerinde meydana gelen artışların da 116 Türev Finansal Varlıklar hesabında izlenen döviz opsiyon sözleşmesine artış olarak kaydedilmesi ve 648 Türev Finansal Araç Karları hesabında gelir olarak gösterilmesine ilişkin kayıtlar yukarıda yer almaktadir.

TMSK tarafından hazırlanan taslak değil de mevcut Tekdüzen Hesap Planına göre kayıtlar yapılsayd1, 4. yevmiye maddesindeki kur zararları 656 Kambiyo Zararları hesabına kaydedilecekti. 5. yevmiye maddesinde ise döviz opsiyon sözleşmesi değeri 118 Diğer Menkul Kıymetler Hesabına borç ve 649 Diğer Olağan Gelir ve Karlar hesabına alacak kaydı yapilacaktı.

6 numaralı yevmiye maddesinde, ödemenin yapıldığı 19.03.2014 tarihinde kurdaki düşüş karşısında, satıcılara olan borcun azalması ve bu borç azalmasından kaynaklanan gelirin 666 Kur Farkı Karları hesabına kaydedilmesi yer almaktadır. Mevcut Tekdüzen Hesap planına göre 646 Kambiyo Karları hesabı kullanılacaktır.

7 numaralı yevmiye maddesinde, opsiyon sözleşmesinin değerinde meydana gelen düşüş nedeniyle menkul kıymet değerindeki azalış ve bu azalış nedeniyle maruz kalınan giderin 658 Türev Finansal Araç Zararları hesabında izlenmesine ilişkin kayıtlar yer almaktadır. Mevcut tekdüzen hesap planında bu hesap yerine 659 Diğer Olağan Gider ve Zararlar hesabının kullanılması uygun olacaktır.

8 numaralı yevmiye maddesinde ise, satıcılara ödemenin yapılması nedeniyle 320 Satıcılar hesabı kapatılmıştır. Karşılığında ise 116 Türev Finansal Araçlar hesabında izlemiş olduğumuz döviz opsiyon sözleşmesinin borç bakiyesi kapatılmıştır. Geriye kalan kısım ise kasadan çıkış şeklinde muhasebeleştirilmiştir. 


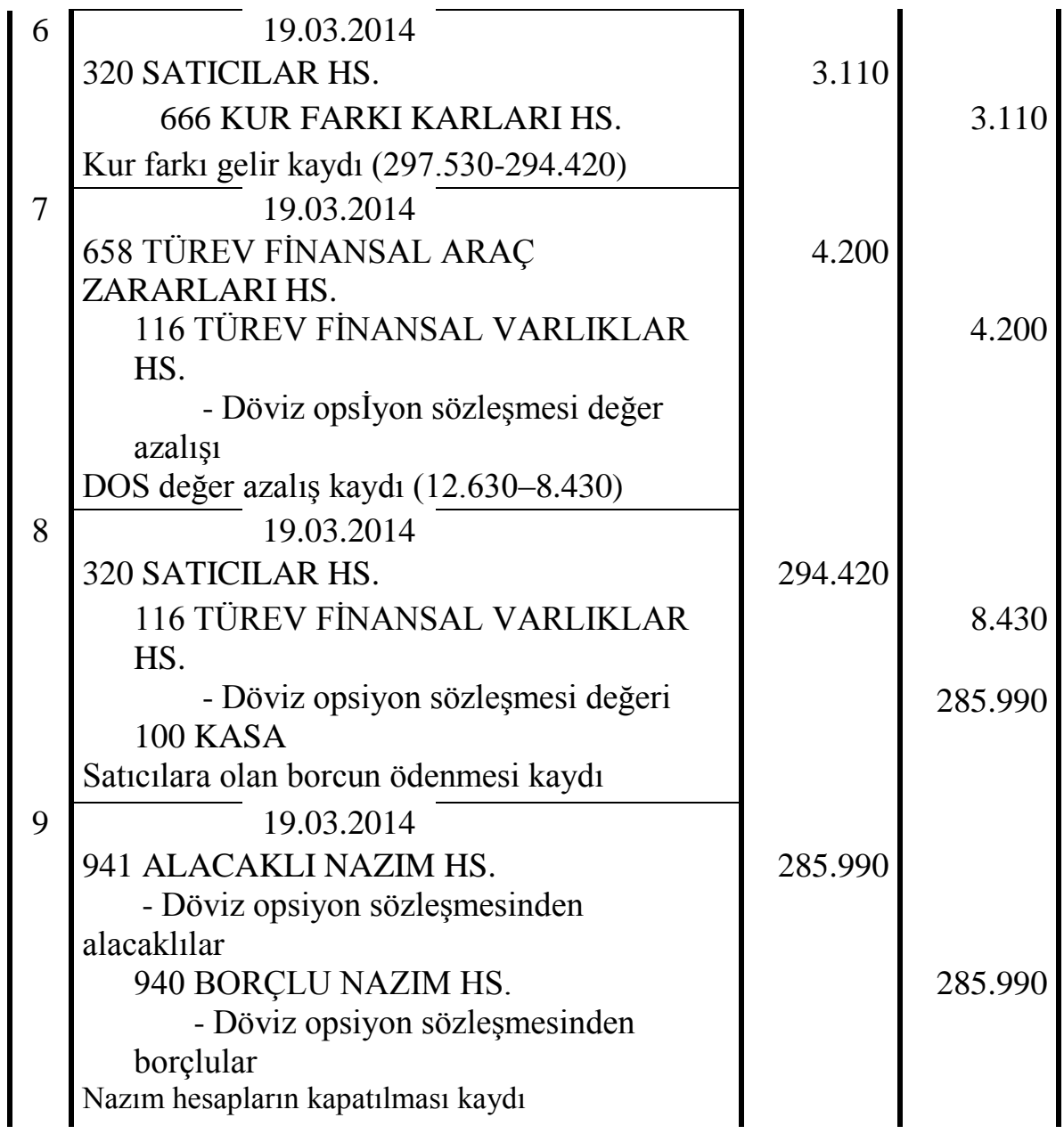

Satın alınan opsiyon sözleşmesine ilişkin kayıtların son aşamasını oluşturan 9 numaralı yevmiye maddesinde ise, 3. yevmiye maddesinde açılmış olan nazım hesaplar kapatılmıştır.

Yevmiye kayıtlarının büyük defter kayıtlarına aktarılmış hali aşağıdaki "T" cetvellerinde topluca gözlenmektedir:

153 TİCARİ MALLAR HS.

(1) 275.430

116 TÜREV FINANSAL VARLIKLAR HS.

(2) $\quad 3.200 \quad 4.200 \quad(7)$

(5) $\quad 9.430 \quad 8.430 \quad$ (8)

320 SATICILAR HS..

\begin{tabular}{lr|rr}
$(6)$ & 3.110 & 275.430 & $(1)$ \\
(8) & 294.420 & 22.100 & $(4)$
\end{tabular}

100 KASA HS.

\begin{tabular}{r|rr}
$* 100.000 .000$ & 3.200 & $(2)$ \\
285.990 & $(8)$
\end{tabular}




\begin{tabular}{l} 
676 KUR FARKI \\
ZARARLARI HS. \\
\hline (4) 22.100
\end{tabular}

\section{TÜREV FINANSAL}

ARAÇ KARLARI HS.

\begin{tabular}{l|l|l}
\hline & $9.430 \quad(5)$ \\
940 BORÇLU NAZIM HS. \\
\hline (3) 285.990 & $285.990 \quad$ (9)
\end{tabular}

666 KUR FARKI KARLARI

HS.

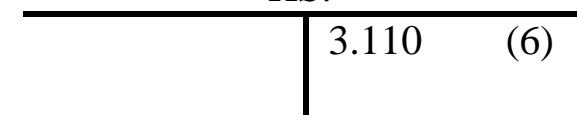

658 TÜREV FINANSAL

ARAÇ ZARARLARI HS.

(7)

4.200

941 ALACAKLI NAZIM HS.

\begin{tabular}{ll|ll}
\hline (9) & 285.990 & $285.990 \quad$ (3)
\end{tabular}

* Kasa hesabı alacak bakiyesi vermeyeceği için, işletmenin kasasında 100.000.000 TL para olduğu varsayılıp büyük defter kayıtlarına o şekilde yansıtılmıştır.

Türkiye "A" işletmesi opsiyon sözleşmesi satın almamış olup, vadesi geldiğinde ödemeyi gerçekleştirseydi, 19.03.2014 tarihindeki kur üzerinden $(10.000 * 10 * 2,9442) 294.420$ TL ödeme yapacaktı. Malı aldığı 17.10.2013 tarihindeki kur üzerinden 275.430 TL olan borcuna karşıllk 19.03.2014 tarihinde 294.420 TL ödeyecekti. Ticarete konu işlem nedeniyle (294.420-275,430) 18.990 TL kur zararına maruz kalacakt1.

Türkiye "A" işletmesi opsiyon sözleşmesi satın almak suretiyle, aracı kurumla belirlenen sözleşme fiyatı üzerinden $(10.000 * 10 * 2,8599) 285.990$ TL karşılığında 100.000 EURO almaya hak kazanmıştır. Döviz opsiyon sözleşmesi sayesinde (294.420-285.990) 8.430 TL tutarında daha az ödeme yapılmıştır. Opsiyon sözleşmesi primi olarak ödenen 3.200 TL de dikkate alındığında TC “A” işletmesi 285.990+3.200=289.190 TL kasasından çıkmak suretiyle borcundan kurtulmuştur. Nihai duruma baktığımızda (294.420-289.190) 5.230 TL daha az ödeme yapılmıştır.

Sonuç olarak Türkiye "A" işletmesi, Almanya "B" işletmesi ile gerçekleştirdiği ticari faaliyet neticesinde maruz kalabileceği 18.990 TL tutarındaki kur zararını, döviz opsiyon sözleşmesi satın almak suretiyle 5.230 TL düşürmüş olup, (18.990-5.230) 13.760 TL ile sınırlandırmıştır.

Yurt dışından Almanya "B" işletmesinden EURO üzerinden ticari mal alımı yapan Türkiye "A" işletmesinin ödemenin yapıldığı tarihteki bilanço ve gelir tablosu üzerindeki etkisine bakacak olursak:

Bilançoda ticari mal hesabında 275.430 TL tutarında bir artış, buna karşılık kasa hesabında 289.190 TL tutarında bir azalış gözlenecektir. Aradaki (13.760) TL tutarındaki 
olumsuz fark, döviz opsiyon sözleşmesindeki kur ile mal alış anındaki kur arasındaki farktan kaynaklanmıştır.

Gelir tablosunda ise, Kur Farkı Karları (Mevcut tekdüzen hesap planına göre Kambiyo Karları) hesabında 3.110 TL ve Türev Finansal Araç Karları (Mevcut tekdüzen hesap planına göre Diğer Gelir ve Karlar) hesabında 9.430 TL olmak üzere toplam 12.540 TL tutarında artış gözlenecektir. Benzer şekilde Kur Farkı Zararları (Mevcut tekdüzen hesap planına göre Kambiyo Zararları) hesabında 22.100 TL ve Türev Finansal Araç Zararları (Mevcut tekdüzen hesap planına göre Diğer Olağan Gider ve Zararlar) hesabında 4.200 TL olmak üzere toplam 26.300 tutarında artış gözlenecektir. Aradaki (13.760) TL tutarındaki olumsuz fark, kur farklarından ve döviz opsiyon sözleşmesi eğerindeki değişimlerden kaynaklanmıştır.

Şayet ödeme günündeki cari kur sözleşme ile belirlenmiş olan 2,8599TL'den daha düşük bir düzeyde olsayd, örnekte yer alan "A" işletmesi sözleşmeden vazgeçme hakkını kullanacaktı. Bu durumda işletme, "B" işletmesine olan borcunu, sözleşme fiyatından daha düşük olan cari kur üzerinden kapatacak ve opsiyon sözleşmesi satın almak nedeniyle uğradığı zarar başlangıçta ödemiş olduğu prim ile sınırlı olacaktı.

\section{SONUÇ VE DEĞERLENDİRME}

Gelecekle ilgili belirsizliklerden kaynaklı çeşitli işlem riskleri altında ticari faaliyetlerinin yürüten işletmelerin, karşı karşıya olduğu risklerden biri de döviz kurlarındaki dalgalanmalardır. Kur farklarından kaynaklı işlem riskleri karşısında kendilerini korumak isteyen işletmelerin başvurdukları yollardan biri de döviz opsiyon sözleşmeleridir. Döviz opsiyon sözleşmeleri, ödenen prim karşılığında belirli miktarda dövizi, belirli bir kur üzerinden sözleşme tarihinin bitiminde veya bu tarihten önce satın alma veya satma hakk1 veren anlaşmalardır. Bu sözleşmelerin kullanılma, muhasebe kayıtlarına alınma, kayıtlardan çıkarılma ve mali tablolara yansıtılma esaslarını belirlemek üzere uluslararası ve ulusal çerçevede çeşitli standartlar getirilmiştir. $\mathrm{Bu}$ standartların getirilmesindeki amaç uygulamalarda yeknesaklığı sağlamak ve karşılaştırılabilirliği mümkün kılmaktır. Bu çerçevede önceden getirilmiş olan standartlar geliştirilerek yenilenmektedir ve değişim devam etmektedir.

Çalışmada döviz opsiyon sözleşmeleri hakkında bilgiler verilmiştir. Ardından da yurt dışından EURO üzerinden ticari mal satın alımı yapan, ödemeyi ileri bir tarihte o günkü EURO kuru üzerinden gerçekleştirecek olan ve kurlarda yaşanabilecek olası bir yükselişten olumsuz etkilenmemek üzere döviz alım opsiyon sözleşmesi satın alan bir işletme ele alınmıştır. İlgili işletmenin döviz alım opsiyon sözleşmesi satın almak suretiyle, kur artışlarından daha az etkilendiği, olası kur zararını azaltarak asgari düzeye indirdiği gözlenmiştir. Döviz alım opsiyon sözleşmesini kullanan işletmenin (alıcı tarafın) muhasebe kayıtlarına çalışmada yer verilmiştir.

Muhasebeleştirme işleminde dönemin kuruluşlu TMSK tarafından belirlenmiş ve daha sonra geri çekilmiş olan Muhasebe Standartlarına uygun taslak hesap planı dikkate alınmıştır. 
$\mathrm{Bu}$ taslak kesinleşmemiş olup henüz uygulamaya konmamıştır. İlgili Bakanlar Kurulu Kararına göre belirli nitelik ve ölçekteki işletmeler finansal raporlamalarını TFRS uyumlu olarak hazırlayacaklardır. Ancak kayıtlar VUK uyumlu olarak devam edecektir. Buna karşın bu çalışmada bir öneri olarak taslaktaki hesap isimleri ve kodları kullanılmıştır. Ayrıca ilgili hesaplara ilişkin mevcut tekdüzen hesap planındaki hesaplar da yevmiye kayıtlarının altında yer alan açıklamalarda belirtilmiştir. Kayıtlarda ikilik olmaması ve çelişkileri durumlara yer vermemek adına, KGK gözetiminde ilgili meslek örgütleri ve akademik camia tarafından taslak hesap planının tamamlanması ve uygulamaya konulmasında fayda vardır.

\section{KAYNAKLAR}

Akbulut, Akın - Üçkuyu, Süleyman- Ceylan, Mehmet Ali- Boyraz, Fazıl- Topaloğlu, MusaKöroğlu, Musa- Arslan, Yavuz. (2011). TMS/TFRS/KOBİ Standartlarına Göre Hesaplanan Ticari Kardan Mali Kara Geçiş. Ankara: TÜRMOB Yayınları-414

Akay, Hüseyin - Akgül, B. Ataman (2003). Uluslararası Muhasebe Standartları ve Türkiye'de Uygulama Etkinliğine İlişkin Bir Araştırma. İstanbul: Türkmen Kitabevi

Akkum, Tülin (2000), "Döviz Opsiyonları ve Opsiyon Fiyatlama Modelleri”, İstanbul Üniversitesi İşletme Fakültesi Dergisi, C:29, S:1/Nisan 2000

Anbar, Adem - Alper, Değer (2011), "Bankaların Türev Ürün Kullanım Yoğunluğunu Etkileyen Faktörlerin Belirlenmesi”, Muhasebe ve Finansman Dergisi, Nisan/2011, ss. 77-94.

Bak, Başak (2009), “ Borsa Opsiyon Sözleşmesi”, Ankara Üniversitesi SBF Dergisi,ss.64-4

Bline, M.Dennis - Fischer, L. Marry - Skekel, D. Ted (2004). Advanced Accounting, USA: John Wiley \& Sons, Inc

Bookstaber, M. Richard (1987). Option Pricing \& Investment Strategies, Chicago:Probus Publishing Company

Çelik, İsmail (2012), Vadeli İşlem Piyasasında Fiyat Keşfi: İzmir Vadeli İşlem ve Opsiyon Borsasında Ampirik Bir Uygulama, Türkiye Bankalar Birliği Yayınları, İstanbul.

Dubofsky, A. David (1992), Options and Financial Futures:Valuation and Uses. Singapore:McGraw-Hill, Inc.

Haftacı, Vasfi- Pehlivanlı, Davut (2007), “UMS 39 ve Uygulamada Karşılaşılan Sorunlar”, Kocaeli Üniversitesi Sosyal Bilimler Enstitüsü Dergisi, Say:13. 2007/1, ss.139-151.

Healy, John (2004), “Financial Instruments -IAS-39:A Moveable Feast For Accountants?", Accountancy Ireland, December 36/6, ss.16-18.

Karaca, Nevran- Hacıhasanoğlu, Tansel - Demirci, D.Şuayyip (2014), “TMS 39 ve TFRS 9 Standartları Kapsamında Endeks Opsiyon Sözleşmelerinin Muhasebeleştirilmesi-BİST 30 Endeks Opsiyon Sözleşmeleri Örneği”, İşletme Araştırmaları Dergisi,ISSN:13090712 
Karagözoğlu, Ahmet (2005), “Gelişmekte Olan Piyasalarda Türev Sözleşmeleri. Vadeli İşlem ve Opsiyon Borsası”, VOBJEKTIF, Kasım 2005, ss.15-22. http://www.vob.org.tr/ VOBPortalTur/docs/vobjektif07.pdf (13.10.2014)

Kaygusuz, S. Yüksel (1998), “Finansal Türev Ürünlerinde Muhasebe Esasları”, SPK yayın no:113,Ankara: Pelin Ofset

Kurtay, Selma (1997). Foreign Currency Options- Market Structure, Pricing, Strategies and Accountancy, Ankara: Sermaye Piyasası Kurulu Yayınları-76

Marshall, F. John Ve Bansal, K. Vipul (1992). Financial Engineering. New York: New York Institute of Finance.

Melvin, Michael (1989). International Money and Finance. USA: Harper \& Row Pub.

Ocakoğlu, Orçun (2013), “Türev Ürünlerinin Muhasebeleştirilmesi”, Mali Çözüm Dergisi, Kasım-Aralık

Önce, Saime (1995), Türev Ürünlerin Muhasebe Sorunları ve Bankalar İçin Muhasebeleştirme Şekilleri, Türkiye Bankalar Birliği, Yayın No: 192. Eskişehir.

Örten, Remzi - Örten, İpek (2001), Türev Finansal Araçlar ve Muhasebe Uygulamaları. Ankara: Gazi Kitabevi.

Redhead, Keith. - Hughes, Steward (1988), Financial Risk Management, England, Gower Publishing Company.

Selvi, Yakup - Türel, Aslı - Yılmaz, K. Mustafa - Kurun, Engin (2007). "Türev Ürün Sözleşmelerinin Reel Sektör Şirketleri Tarafından Kullanımı ve Riskten Korunma Muhasebesi Açısından Değerlendirilmesi: İMKB-100 Şirketleri Üzerinde Bir İnceleme”, Muhasebe Bilim Dünyası Dergisi, Cilt.9, Sayı.4, Aralık 2007, ss.225-258.

Seyidoğlu, Halil (1997), Uluslararası Finans. İstanbul: Güzem CanYayınları

Şavlı, Tuba (2014), Uluslararası/Türkiye Finansal Raporlama Standartları, Yaklaşım Yayınc1l1k, Ankara.

Tenker, Nejat (2004). "IAS 39 Uygulamalarının Düşündürdükleri”, FBE Journal, Review of Social, Economic\&Business Studies. Vol.3/4, ss. 286-295

TMSK, (2010). Uluslararası Finansal Raporlama Standartları (IFRS/IAS) ile Uyumlu TMS. Ankara: TMSK Yayınları-5

Türev Ürünler Lisanslama Rehberi. (2006). Vadeli İşlem ve Opsiyon Borsası AŞ Yayınları, Ekim 2006, İzmir.

Usta, Öcal (2002).İşletme Finansı ve Finansal Yönetim. Anadolu Matbaacılık, 1.Baskı,İzmir

Uzun, Ebru (2004). Türkiye'deki Uygulamalar, 39 Numaralı Uluslararası Muhasebe Standardı ve Avrupa Merkez Bankası Uygulamaları Çerçevesinde Türev Ürünlerin Muhasebeleştirilmesi ve Finansal Tablolara Yansıması, TC Merkez Bankası Muhasebe Genel Müdürlüğü Uzmanlık Yeterlilik Tezi. 
http://www.bis.org/publ/rpfxf10t..pdf,. .) ( 03.05.2014) Bank for International Settlements, Triennial Central Bank Survey "Report on global foreign Exchange market activity in 2010”, December 2010. P:7 (03.05.2014)

http://www.bis.org/publ/cpss95.pdf, ( 03.05.2014) Bank for International Settlements -BIS, "Statistics on payment and settlement systems in the CPSS countries figures for 2009" March 2011, P.370 Table 20 and Table 21. 
